\title{
Accounting
}

\section{The effect of debt covenant, political cost and IFRS implementation towards the company value}

\author{
Ahalik $^{\mathrm{a}^{*}}$, Adji Suratman ${ }^{\mathrm{b}}$ and Nuzulul Hidayatic
}

${ }^{a}$ Accounting Study Program, Sekolah Tinggi Manajemen PPM, Jakarta, Indonesia

${ }^{b}$ Accounting Study Program, Sekolah Tinggi Ilmu Ekonomi YAI, Jakarta, Indonesia

${ }^{c}$ Faculty of Economics and Business, Universitas Persada Indonesia YAI, Jakarta, Indonesia

\section{H R O N I C L E}

\section{Article history:}

Received: September 28, 2020

Received in revised format:

December 282020

Accepted: December 28, 2020

Available online:

January 15, 2021

Keywords:

Debt Covenant

Political Cost

Implementation of IFRS

Firm Value

Economic Value Added (EVA)

Positive Accounting Theory

\section{A B S T R A C T}

The research is aimed to analyze the influence of debt covenant, political cost and implementation of IFRS toward firm value. The population in this research are non public companies in the period 2016, 2017 and 2018. Non public companies are used as the population in this research to see the level of implementation of IFRS that have been applied by non public companies. The sample selection by using a random method and obtaining a sample of 46 companies or 138 observation data. The analysis used in this research is a Panel Data Regression by using Eviews 10.00. The partial result showed that political cost and implementation of IFRS affect firm value, while the debt covenant does not affect firm value. And the simultaneous result showed that debt covenant, political cost and implementation of IFRS affect firm value.

\section{Introduction}

The company was founded with the aim of seeking maximum profit. Apart from looking for profit, the company also tries to increase the company value. In the current digital economy era, the value of companies that have not been around for a long time has increased rapidly and beats the value of companies that have been around for decades. One of the phenomena that occurred in 2019 was that Gojek's currency was bigger than Garuda Indonesia. Gojek is a technology company from Indonesia that serves transportation through motorcycle taxi services, this company was founded in 2010 (gojek.com). As for the things that cause Gojek's valuation to be 14 times greater than Garuda Indonesia's market capitalization, some investors have injected funds into Gojek so that it can hold the status of decacorn. Gojek's valuation is greater because business analysis in the digital era has changed, where assets are no longer tangible like those of Garuda Indonesia, but there are intangible assets that cannot be guaranteed by banks but are attached to the company, such as skills, innovations, ideas and so on (kompas.com). High values of the company will increase investors' trust towards the Company. Therefore, the Company will get sufficient funding to finance its operational activities. Firm value can not only be described in the company's stock price, but can be seen from the financial perspective.

* Corresponding author. Tel.: +628161691121

E-mail address: ahalik@ppm-manajemen.ac.id (Ahalik) 
According to Watt \& Zimmerman (1986), the debt-equity hypothesis states that a company with a high-debt-funding structure will choose the appropriate accounting method in order to fulfill the credit agreement, where the accounting policies used can affect the company's profit value until finally the company value is based profits will also be affected. Meanwhile, the politicalcost hypothesis states that large companies can be in the public spotlight where they will choose an accounting method that moves the current year's profit to the next year in order to minimize political costs. The higher size of the Company will be closely related to the funding decisions that will be implemented by the company in order to optimize the Company value (Suwardika \& Mustanda, 2017).

Indonesia is the only country in Southeast Asia that is included in the G20 forum which agreed to refer to IFRS (International Financial Reporting Standard) in preparing its accounting standards. The application of IFRS convergence can have various benefits, including increasing comparability and transparency of financial reports, producing quality information on the international capital market, and global economic integration (A'isa \& Vestari, 2019). The implementation of IFRS in accounting policies in companies can affect company profits and attract the attention of investors in investing in the company so that the company value will also increase. Thus, this research was conducted to see the effect of debt covenants, political costs and IFRS implementation towards firm value.

\section{Literature survey}

\subsection{Agency Theory and Positive Accounting Theory (PAT)}

According to Jensen and Meckling (1976), agency theory is a contract in which one or more parties called the principal ask the other party, namely the agent, to do some work on behalf of the principal. In agency theory, there is a conflict of interest between the agent and the principal. The agent as the recipient of capital will perform the best in managing the resources it receives. However, it cannot be guaranteed that the agent will always act in the best interest of the principal. This condition can lead to conflict in the agency relationship.

\subsubsection{Bonus plan}

The bonus-plan hypothesis states that companies with a profit-based bonus program will choose an accounting method that will increase profits in the current period. Therefore, management gets a high bonus.

\subsubsection{Debt Covenant}

The debt-equity hypothesis states that companies with high debt-to-capital financing structures will choose the appropriate accounting method in order to fulfill the credit agreement.

\subsubsection{Political cost}

The political-cost hypothesis states that large companies can be in the public spotlight where they will choose an accounting method that moves current year's profits to the next year.

\subsection{Theory of the firm}

Agustini (2018) states that companies are basically economic actors. Therefore, the company's activities can be understood in the context of the company's economic model. The basic model of the firm's economy is derived from the theory of the firm. According to firm theory, the firm's goal is assumed to be profit maximization. The purpose of maximizing the value or wealth of the company (wealth maximization) has become the goal of many companies today than the goal of maximizing short-term profits. This occurs as the emphasis on profit changes and to deal with uncertainty and changing times. Adenugba et al. (2016) also state that the goal of each company is to generate profits and maximize owner's wealth. To achieve this goal, a company needs to seek funds to finance the operations and activities of the company. A high company value has benefits, such as access to funding from the capital market or money market, as well as high company prices in the eyes of investors when the company wants to be acquired. Company value is very important because it will affect the welfare of shareholders.

\subsection{Earning management theory}

According to Scott (2009), earning management is a manager's choice of accounting policies or actions that affect the assessment to achieve some of the reported specific valuation objectives. Scott (2009) also divides the understanding of earnings management into two. First, see it as the opportunistic behavior of managers to maximize their utility in facing compensation contracts, debt contracts and political costs (opportunistic earnings management). Second, by looking at earnings management 
from the perspective of efficient contracting (efficient earning management), where earnings management gives managers the flexibility to protect themselves and the company in anticipating unforeseen events for the benefit of the parties involved in the contract. If earnings management is opportunistic, this earnings information can lead to wrong decision making for investors.

\subsection{International Financial Reporting Standard (IFRS)}

The International Financial Reporting Standard (IFRS) is designed as a common global language for business dealings so that corporate financial reports are understandable, reliable, relevant and comparable across international boundaries. IFRS is a consequence of the increase of international ownership and trade, very important for companies that have transactions in several countries. IFRS is progressively replacing many different national accounting standards. IFRS includes: IFRS issued by the IASB; International Accounting Standards (IAS) issued by the IASC, or its revisions issued by the IASB (Yahya et al., 2016). IFRS is the accounting standard used by European countries and will become a global standard where Indonesia as a member of the G20 has committed to convergence with IFRS. The implementation of IFRS in Indonesia came into effect on January 1, 2012 where the existing PSAK (Statement of Financial Accounting Standards) has largely converged with IFRS. Jang et al. (2016) summarizes four main differences between GAAP and IFRS standards, namely, firstly rule-based GAAP, whereas IFRS is principles-based (with expectations of increased management policy after adoption). Second, the company will submit a consolidated report under IFRS rather than multiple financial statements (with an expected increase in comparability and value relevance). Third, IFRS expands the scope of fair value accounting. Fourth, it is expected to provide improvements in the quality and quantity of the disclosure of footnotes.

\subsection{Company value}

Company value is one measure of the success of future company management and is able to increase the company's credibility to shareholders. If the needs of shareholders are met, it will have a good impact on the Company value. Considering the goal of increasing the value of the company, companies need to be careful in making decisions and considering their effect on share prices. For management, the company value is an indicator for investors about the company's past performance and future company prospects (Setiadharma \& Machali, 2017). According to Hardinis (2019), company value is the investor's perception of the company, which is often associated with stock prices. The main objective of the company, according to company theory, is to maximize the wealth or value of the company. Maximizing the value of a company is very important for a company. In fact, by maximizing the company value, it will maximize shareholder wealth, which is the main objective of the company.

\section{Theoretical framework}

Based on Fig. 1 which represents the Theoretical Framework, the hypothesis is formed as follows:

$\mathrm{H}_{1}$ : Debt Covenant has an effect towards the Company value.

$\mathrm{H}_{2}$ : Political Cost has an effect towards the Company value.

$\mathrm{H}_{3}$ : The implementation of IFRS has an effect towards the Company value.

$\mathrm{H}_{4}$ : Debt Covenant, Political Cost, and the Implementation of IFRS, together, had some effects towards the Company value.

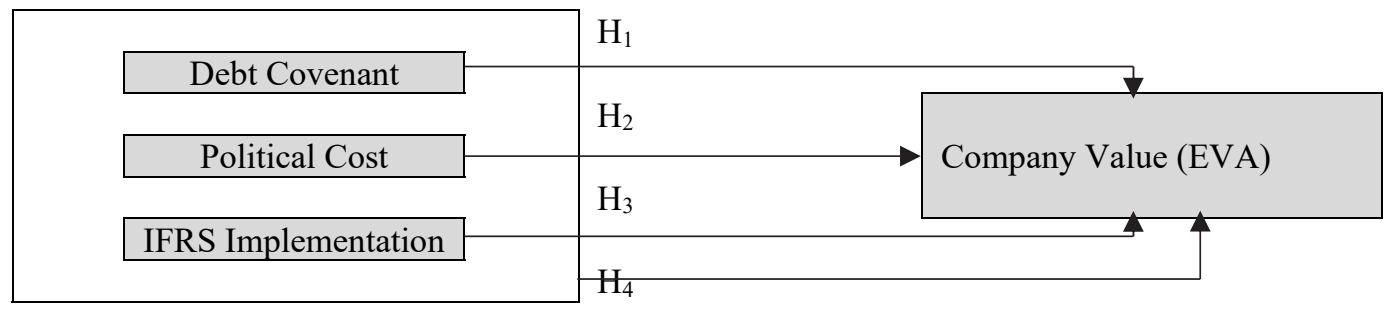

\section{Research model}

\subsection{Research population and method}

This research is a causal research with a quantitative approach. The research population was non-public companies in 2016, 2017 and 2018. Non-public companies were the population in the research because IFRS implementation was only required for public companies, state-owned corporations (BUMN) and companies under The Financial Services Authority (OJK). Therefore, we could see how far IFRS has been implemented by non-public companies. The sampling technique used is the random method (random), obtaining a research sample of 46 companies or 138 research data. 


\subsection{Research variable}

\subsubsection{Debt Covenant (LV)}

Debt Covenant is proxied with leverage (Al-Slehat, 2020), which is as follows:

$$
\text { Leverage }=\frac{\text { Total debt }}{\text { Total capital }}
$$

\subsubsection{Political cost (PC)}

Political Cost is proxied by company size which can be seen from total assets (Setiadharma \& Machali, 2017), as follows:

$$
\text { Company's size }=\text { Ln Tota }
$$

\subsubsection{The implementation of IFRS}

The Implementation of IFRS is measured by the percentage of the number of points in accordance with the company's financial statements compared to the total points (developed by the author, see appendix), as follows:

$$
\operatorname{IFRS}=\frac{N}{24} x
$$

where, $\mathrm{N}$ is the number of points obtained per company with value range per question is $0-1$ of 24 questions.

\subsubsection{Company value (EVA)}

Firm value is measured using EVA because the sample in this research is a non-public company which does not have a number of outstanding shares. Thus, EVA is chosen as a research measurement so that it can be used in accordance with the consideration of the sample in the research. The measurement of EVA (Horngren, et al., 2015) is as follows:

$\mathrm{EVA}=$ Net Profit $-\mathrm{WACC}($ Long term debt + Equity $)$

$\mathrm{WACC}=($ After tax interest expense + Dividend $) /($ Total long term debt + Total common stock $)$

\section{Research results}

\subsection{Data analysis}

The model used in this research is a panel data regression combination of time series and cross section data, using the help of a statistical computer application program, Eviews 10.0. In this research, a test will be carried out on the determinants of IFRS implementation and its implications towards the Company Value.

\subsection{Descriptive statistics}

Table 1

Descriptive Statistics

\begin{tabular}{ccccc}
\hline & EVA & LV & PC & IFRS \\
\hline Mean & $2.00 \mathrm{E}+09$ & 2.760460 & 25.01568 & 0.921087 \\
Median & -28624142 & 0.283850 & 25.13590 & 1.000000 \\
Maximum & $1.27 \mathrm{E}+11$ & 1470.088 & 28.04910 & 1.000000 \\
Minimum & $-6.30 \mathrm{E}+10$ & -1154.661 & 19.98680 & 0.250000 \\
\hline Std. Dev. & $1.81 \mathrm{E}+10$ & 174.9693 & 1.789258 & 0.159747 \\
\hline Skewness & 2.500566 & 2.075105 & -0.857425 & -2.814726 \\
Kurtosis & 20.41266 & 52.26313 & 3.753211 & 11.25248 \\
\hline Jarque-Bera & 1887.220 & 14053.46 & 20.17123 & 573.8166 \\
Probability & 0.000000 & 0.000000 & 0.000042 & 0.000000 \\
Sum & $2.76 \mathrm{E}+11$ & 380.9435 & 3452.163 & 127.1100 \\
Sum Sq. Dev. & $4.49 \mathrm{E}+22$ & 4194151. & 438.5980 & 3.496137 \\
\hline Observations & 138 & 138 & 138 & 138 \\
\hline
\end{tabular}


Based on Table 1 - Descriptive Statistics, the highest standard deviation is on the Company Value (EVA) variable in the amount of 18,098,056,396.53, while the IFRS Implementation variable (IFRS) has the lowest standard deviation of 0.159747. The variable Company Value (EVA) and Debt Covenant (LV) have a positive skewness values, while the Political Cost (PC) and IFRS Implementation (IFRS) variables have a negative skewness value. All variables, namely Company Value (EVA), Debt Covenant (LV), Political Cost (PC) and IFRS Implementation (IFRS) have a kurtosis value greater than 3 . Therefore, the distribution curve is called leptokurtic.

\subsection{Data panel model}

\subsubsection{Chow test}

Based on Table 2 Chow Test, the probability value in the Chi-square cross-section is $0.0000<0.05$, which means H1 is accepted, then the model chosen is the fixed effect model compared to the common effect.

\section{Table 2}

The summary of Chow test

\begin{tabular}{llll}
\hline Effects Test & Statistic & d.f. & Prob. \\
\hline Cross-section F & 7.152178 & $(45,89)$ & 0.0000 \\
Cross-section Chi-square & 211.083002 & 45 & 0.0000 \\
\hline
\end{tabular}

\subsubsection{Lagrange multiplier}

Based on Table 3 Langrange Multiplier Test, the probability value in the Breusch-Pagan cross-section is $0.0000<0.05$, which means $\mathrm{H} 1$ is accepted, the model chosen is the random effect model compared to the common effect.

Table 3

The summary of Langrange multiplier test

\begin{tabular}{|c|c|c|c|}
\hline & & Test hypotheses & \\
\hline & Cross-section & Time & Both \\
\hline \multirow[t]{2}{*}{ Breusch-Pagan } & 59.04014 & 1.501751 & 60.54190 \\
\hline & $(0.0000)$ & $(0.2204)$ & $(0.0000)$ \\
\hline \multirow[t]{2}{*}{ Honda } & 7.683758 & -1.225459 & 4.566707 \\
\hline & $(0.0000)$ & -- & $(0.0000)$ \\
\hline \multirow[t]{2}{*}{ King-Wu } & 7.683758 & -1.225459 & 0.385936 \\
\hline & $(0.0000)$ & -- & $(0.3498)$ \\
\hline \multirow[t]{2}{*}{ Standardized Honda } & 8.032392 & -0.999545 & 0.007540 \\
\hline & $(0.0000)$ & -- & $(0.4970)$ \\
\hline \multirow[t]{2}{*}{ Standardized King-Wu } & 8.032392 & -0.999545 & -1.944014 \\
\hline & $(0.0000)$ & -- & -- \\
\hline \multirow[t]{2}{*}{ Gourierioux, et al.* } & -- & -- & 59.04014 \\
\hline & & & $(<0.01)$ \\
\hline
\end{tabular}

\subsubsection{Hausman Test}

In Table 4 the Hausman Test, the probability value in the random cross-section is $0,2456>0.05$, which means that $\mathrm{H} 0$ is accepted, then the model chosen is the random effect model compared to the fixed effect.

\section{Table 4}

The summary of Hausman test

\begin{tabular}{llll}
\hline Test Summary & Chi-Sq. Statistic & Chi-Sq. d.f. & Prob. \\
\hline Cross-section random & 4.151161 & 3 & 0.2456 \\
\hline
\end{tabular}

Based on the results of testing using the Chow Test, Langrange Multiplier (LM) Test, and Hausman Test towards the three panel data regression models, it shows that the random effect is the best or the most appropriate model to be used in this research. Therefore, the interpretation of the respective model will be used in explaining the phenomenon based on the research data.

Based on Fig. 2 - Normality Test, it shows that there is a slope to the left and in the statistical test, the probability value is $0.000095<0.05$. Therefore, it shows that the observed data is not normally distributed. According to Harinaldi (2005), based on the Central Limit Theorem, a population is not normally distributed if the sample size is large enough ( $\mathrm{n}>30)$. Therefore, the results of this research states that data, that is not normally distributed, can be ignored. 


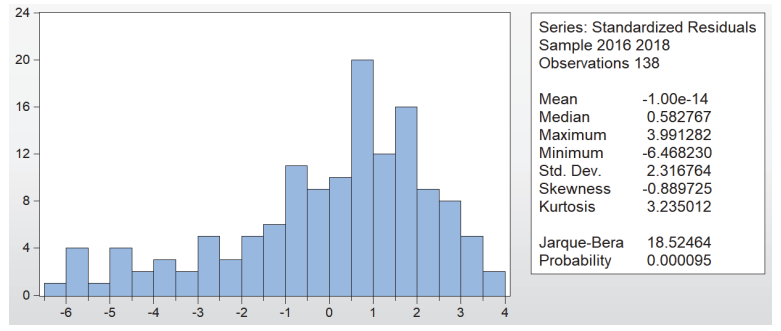

Fig. 2. Testing the normality

In addition, multicollinearity test shows the correlation value of each independent variable is $<0.8$. Therefore, it can be concluded that there is no multicollinearity.

\section{Table 5}

The correlation results

\begin{tabular}{ccrc}
\hline & LV & PC & IFRS \\
\hline LV & 1.000000 & -0.133449 & -0.014020 \\
PC & -0.133449 & 1.000000 & -0.088458 \\
IFRS & -0.014020 & -0.088458 & 1.000000 \\
\hline
\end{tabular}

\section{Table 6}

The results of Heteroscedasticity Test

\begin{tabular}{lllll}
\hline Variable & Coefficient & Std. Error & t-Statistic & Prob. \\
\hline C & 1.645152 & 2.484409 & 0.662191 & 0.5090 \\
LV & $3.47 \mathrm{E}-05$ & 0.000672 & 0.051688 & 0.9589 \\
PC & -0.050324 & 0.089123 & -0.564651 & 0.5733 \\
IFRS & 1.553833 & 0.970747 & 1.600656 & 0.1118 \\
\hline
\end{tabular}

In this research, the heteroscedasticity test was performed using the Glejser test. Table 6 - Heteroscedasticity test shows that the probability value on all variables is $>0.05$. Therefore, it can be concluded that there are no symptoms of heteroscedasticity or it can be said that the data is homoscedasticity in the regression model. Finally, Table 7 shows the results of regression analysis.

Table 7

The summary of the regression results

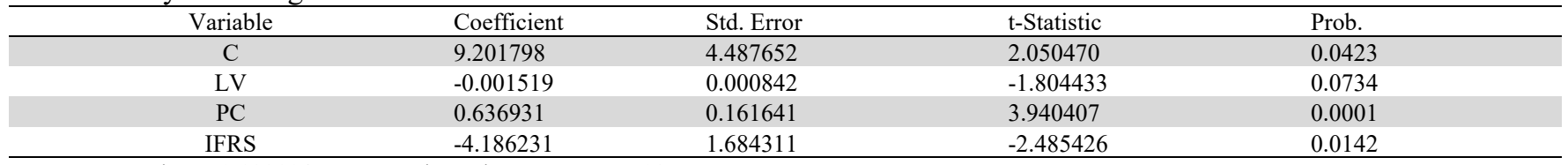

\begin{tabular}{crcc}
\hline R-squared & 0.188114 & Mean dependent var & 7.777708 \\
Adjusted R-squared & 0.169937 & S.D. dependent var & 1.462471 \\
S.E. of regression & 1.332425 & Sum squared resid & 237.8976 \\
F-statistic & 10.34926 & Durbin-Watson stat & 2.103944 \\
Prob(F-statistic) & 0.000004 & &
\end{tabular}

Based on Table 7 - Panel Data Regression Estimation with the Random Effect Model, the following regression models can be obtained:

$$
E V A=9,201798-0,001519 L V+0,636931 P C-4,186231 \text { IFRS }+\varepsilon
$$

\section{Discussion}

\subsection{The Effect of Debt Covenants towards the Company Value}

The result of statistical testing shows the debt covenant (LV) variable has a coefficient value of -0.001519 with a probability value of $0.0734>0.05$, which means that the debt covenant variable has no effect towards the Company value. Thus, the hypothesis, which states that debt covenants affect firm value (H1), is rejected. This result is in line with the research of AlSlehat (2020), Astriani (2014), and Novari \& Lestari (2016) which state that leverage, as a proxy of debt covenants, has no effect towards the Company value. Meanwhile, this result is not in line with the research of Pratama \& Wiksuana (2016), Rudangga \& Sudiarta (2016), and Adenugba, Ige \& Kesinro (2016), which states that leverage, as a proxy for debt covenants, affects the Company value. Based on the research results, the increase or decrease in leverage is not always followed by an 
increase and decrease in the Company value. Moreover, companies tend to use their own capital or share capital to finance its operations rather than debt. Excessive use of debt can reduce the benefits of debt because it is not proportional to the interest rate that must be paid on the debt. Thus, high corporate debt can result in an increase in interest costs which affect the profit and value of the Company.

\subsection{Political Cost Affects The Company Value}

The results of statistical tests show that the political cost (PC) variable has a coefficient value of 0.636931 with a probability value of $0.0001<0.05$, which means that the political cost variable has an effect towards the Company value. Therefore, the hypothesis which states that political cost affects firm value (H2) is accepted. This result is in line with research of Pratama \& Wiksuana (2016), Rudangga \& Sudiarta (2016), Al-Slehat (2020) and Novari \& Lestari (2016) which state that company size as a proxy for political cost affects the Company value. Meanwhile, these results are not in line with the research of Setiadewi \& Purbawangsa (2015), Astriani (2014) and Setiadharma \& Machali (2017) which state that company size as a proxy for political cost has no effect towards the Company value. Based on the research result, company size, as a proxy for political cost measured by total company assets, can affect the Company value. Large companies can increase firm value, because large companies tend to have more stable conditions than small companies. This condition is the cause of the increase in the company's share price in the capital market. Investors have high expectations towards large companies, namely in the form of dividends from the company's profits. The increase in share price can increase the Company's value.

\subsection{The IFRS Implementation Affects The Company Value}

The results of statistical testing show that the IFRS implementation variable (IFRS) has a coefficient value of -4.186231 with a probability value of $0.0142<0.05$, which means that the IFRS implementation variable has an effect towards the Company value. Thus, the hypothesis which states that IFRS implementation affects firm value (H3) is accepted. This result is in line with the research of Salah (2020), Agyei-Boapeah, et al. (2020), and Taiwo and Ajibade (2020) which state that IFRS implementation has an effect on firm value. Meanwhile, these results are not in line with Arniati's (2014) research which states that IFRS implementation has no effect on firm value. IFRS implementation is an accounting standard that can affect the accounting quality. By implementing IFRS in the company's accounting policies, it can positively increase the profit. With the implementation of IFRS, it can produce financial reports that are more relevant, timely manner, trustworthy and transparent so that they have a good effect on the quality of earnings reported in the company. In addition, IFRS is a global accounting standard, with the implementation of IFRS in corporate accounting policies, it can increase the comparability of financial information internationally. Therefore, it can be easier for companies in increasing funding, both in the form of debt and issuance of shares which can be used in the company's operational activities. Thus, the value of the company will also increase along with the increase in the quality of earnings and sufficient funding for the company's operational activities.

\subsection{Debt Covenant, Political Cost, and IFRS Implementation, Together, Affect The Company Value}

The results of statistical tests show that the debt covenant, political cost and IFRS implementation variables together have a probability value of $0.000004<0.05$, which means that the debt covenant, political cost and IFRS implementation variables together have an effect on firm value. Thus, the hypothesis which states that debt covenant, political cost and IFRS implementation together have an effect towards the Company's value (H4) is accepted. Positive accounting theory (PAT) is related to the elements of company profit, where one of the elements in the Company's value is profit. Two hypotheses of positive accounting theory used in this research are debt covenant and political cost. Debt covenant, proxied by leverage, can measure a company's ability to pay long and short term debt using funds originating from loans. Therefore, it could help company management in managing funding in order to increase profits. Political cost, proxied by the size of the company, could be seen from the company's total assets, can see how big the company is, because large companies can have easy access to funding in the form of debt or shares. Therefore, it could be used for company operational activities in increasing profits. The implementation of IFRS as an accounting standard in companies can increase earnings, equity, transparency, and comparability of financial information. Therefore, it could increase the quality of the company's profits which can also increase the value of the company. Thus, collectively, all variables, namely debt covenant, political cost and IFRS implementation can affect firm value.

\section{Conclusion, limitation and suggestion}

Based on the tests that have been carried out, the conclusions obtained are as follows:

1. Debt Covenant has no effect towards the Company Value.

2. Political Cost has an effect towards on the Company Value.

3. IFRS implementation has an effect towards on the Company Value.

4. Debt Covenant, Political Cost, and IFRS Implementation, together, have an effect towards the Company Value. 
This research has limitations, such as:

1. One of the hypotheses in the Positive Accounting Theory is that the Bonus Plan is not used as a research variable.

2. This study only uses three variables to see their effect on the Company's Value, namely Debt Covenant, Political Cost and IFRS Implementation.

3. The research period is only 3 years, namely $2016-2018$.

There are suggestions that can be given so that further research can provide different variations and better results, namely as follows:

1. The researcher can then include the Bonus Plan variable in the research to see its effect towards the Company's Value.

2. Further researchers can use different proxies in measuring the same variable, so that they can see different results with this research.

3. The next researcher can increase the research period so that more data is generated so that the data distribution is better.

\section{References}

A'isa, R. D. \& Vestari, M. (2019). Pengaruh Bonus Plan, Debt Covenant, Political Cost dan Litigation Risk Terhadap Konservatisme Akuntansi Pasca Konvergensi International Financial Reporting Standards. Seminar Nasional dan The 6th Call for Syariah Paper Universitas Muhammdiyah Surakarta, 216-254.

Adenugba, A.A., Ige, A. A. \& Kesinro, O. R. (2020). Financial leverage and firms' value: A study of selected firms in Nigeria. European Journal of Research and Reflection in Management Sciences, 4(1), 14-32.

Agustini, M. Y. D. H. (2018). Ekonomi Manajerial Pembuatan Keputusan Berdasar Teori Ekonomi. Semarang: Universitas Katolik Soegijapranata.

Agyei-Boapeah, H., Machokoto, M., Amankwa-Amoah, J., Tunyi, A., \& Fosu, S. (2020, May). IFRS adoption and firm value: African evidence. In Accounting Forum (pp. 377-397). Blackwell.

Al-Slehat, Z. A. F. (2020). Impact of Financial Leverage, Size and Assets Structure on Firm Value: Evidence from Industrial Sector, Jordan. International Business Research, 13(1), 109-120.

Arniati, T. (2014). Dampak Penerapan IFRS terhadap Nilai Perusahaan (Studi pada perusahaan Sektor Tekstil yang Listing di BEI). Jurnal Akuntansi Bisnis dan Manajemen, 21(2), 154-167.

Astriani, E. F. (2014). Pengaruh Kepemilikan Manajerial, Leverage, Profitabilitas, Ukuran Perusahaan Dan Investment Opportunity Set Terhadap Nilai Perusahaan. Jurnal Akuntansi, 2(1), 1-25.

Harinaldi. (2005). Prinsip-Prinsip Statistik untuk Teknik dan Sains. Jakarta: Erlangga.

Horngren, C. T., Foster, G., \& Datar, S. M. (2001). A managerial Emphasis. Upper Saddle River, New Jersey: Pren.

Jang, J. I., Lee, K. J., Seo, Y., \& Cheung, J. (2016). Economic Consequences Of IFRS Adoption In Korea: A Literature Review. Journal of Applied Business Research (JABR), 32(6), 1649-1662.

Jensen, M. C., \& Meckling, W. H. (1976). Theory of the firm: Managerial behavior, agency costs and ownership structure. Journal of Financial Economics, 3(4), 305-360.

Novari, P. M. \& Lestari, P. V. (2016). Pengaruh Ukuran Perusahaan, Leverage, Dan Profitabilitas Terhadap Nilai Perusahaan Pada Sektor Properti Dan Real Estate. E-Jurnal Manajemen Unud, 5(9), 5671-5694.

Pratama, G. B. A. \& Wiksuana, G. B. (2016). Pengaruh Ukuran Perusahaan Dan Leverage Terhadap Nilai Perusahaan Dengan Profitabilitas Sebagai Variabel Mediasi. E-Jurnal Manajemen Unud, 5(2), 1338-1367.

Rudangga, I. G. N. G. \& Sudiarta, G. M. (2016). Pengaruh Ukuran Perusahaan, Leverage, Dan Profitabilitas Terhadap Nilai Perusahaan. E-Jurnal Manajemen Unud, 5(7), 4394 - 4422.

Salah, W. (2020). The international financial reporting standards and firm performance: A systematic review. Applied Finance and Accounting, 6(2), 1-10.

Scott, W. R., \& O'Brien, P. C. (2003). Financial Accounting Theory (Vol. 3). Toronto: Prentice hall.

Setiadewi, K. A. Y. \& Purbawangsa, I. B. A. (2015). Pengaruh Ukuran Perusahaan dan Leverage Terhadap Profitabilitas dan Nilai Perusahaan. E-Jurnal Manajemen Unud, 4(2), 596-609.

Setiadharma \& Machali. (2017). The Effect of Asset Structure and Firm Size on Firm Value with Capital Structure as Intervening Variable. Journal of Business \& Financial Affairs, 6(4), 2-5.

Suwardika, I. N. A. \& Mustanda, I. K. (2017). Pengaruh Leverage, Ukuran Perusahaan, Pertumbuhan Perusahaan dan Profitablitas Terhadap Nilai Perusahaan pada Perusahaan Properti. E-Jurnal Manajemen Unud, 6(3), 1248-1227..

Taiwo, O. O. \& Ajibade, A. (2020). IFRS Adoption and Economy Performance of Nigeria and Kenya. International Journal of Scientific and Research Publications, 10(7), 369-378.

Watts, R. L., \& Zimmerman, J. L. (1986). Positive accounting theory.

Yahya, K. A., Fagbemi, T. O., Oyeniyi, K. K., \& Sulaiman, A. B. (2015). Impact of IFRS on the Financial Statements Figures and Key Financial Ratios of Nigerian Banks. Journal of Commerce (22206043), 7(3). 
Website:

gojek.com

kompas.com

\section{Appendix}

\section{The implementation of IFRS}

\begin{tabular}{|c|c|c|c|c|c|}
\hline No & IFRS & Question & Value 1 & Value of 0 & $\mathbf{N} / \mathbf{A}$ \\
\hline 1 & IAS 1 & $\begin{array}{l}\text { Name of the report that presents } \\
\text { the position of assets, liabilities and equity. }\end{array}$ & of financial position & Others & N/A \\
\hline 2 & IAS 1 & $\begin{array}{l}\text { Report name that presents information on } \\
\text { profit or loss }\end{array}$ & $\begin{array}{l}\text { Income Statement and other } \\
\text { comprehensive income }\end{array}$ & Others & $\mathrm{N} / \mathrm{A}$ \\
\hline 3 & IAS 2 & Inventory cost formula & $\begin{array}{l}\text { Inventory costs, calculated using the first } \\
\text { in first out (FIFO) formula or weighted } \\
\text { average. }\end{array}$ & Others & N/A \\
\hline 4 & IAS 2 & Measurement of inventory & $\begin{array}{l}\text { Measure inventory using Lower Cost or } \\
\text { Net Realizable Value (LCNRV) }\end{array}$ & Others & N/A \\
\hline 5 & IAS 12 & $\begin{array}{l}\text { The company measures deferred tax assets } \\
\text { and liabilities }\end{array}$ & $\begin{array}{l}\text { Measure deferred tax assets and liabilities } \\
\text { at tax rates and taxable income consistently } \\
\text { with expectations in recovering } \\
\text { or completing assets or liabilities. }\end{array}$ & $\begin{array}{l}\text { The company does } \\
\text { not measure deferred } \\
\text { tax assets and } \\
\text { liabilities }\end{array}$ & N/A \\
\hline 6 & IAS 16 & Measurement of fixed assets & $\begin{array}{l}\text { The entity chooses the cost model or } \\
\text { revaluation model as its accounting policy } \\
\text { and applies the policy to all fixed assets in } \\
\text { the same class. If the carrying amount of } \\
\text { an asset increases as a result of a } \\
\text { revaluation, then the increase is recognized } \\
\text { in other comprehensive income and } \\
\text { accumulated in equity in the portion of the } \\
\text { revaluation surplus. }\end{array}$ & Others & $\mathrm{N} / \mathrm{A}$ \\
\hline 7 & IAS 19 & $\begin{array}{l}\text { The measurement of the employee benefits in } \\
\text { defined benefit plan }\end{array}$ & $\begin{array}{l}\text { Using independent and professional } \\
\text { actuarial for accuracy of assumptions and } \\
\text { measurement. }\end{array}$ & Others & N/A \\
\hline 8 & IAS 19 & $\begin{array}{l}\text { The measurement of the employee benefits in } \\
\text { defined benefit plan }\end{array}$ & $\begin{array}{l}\text { The remeasurement of liabilities (assets) } \\
\text { net defined benefits due to changes in the } \\
\text { assumptions of actuaries is included in } \\
\text { other comprehensive income. }\end{array}$ & Others & $\mathrm{N} / \mathrm{A}$ \\
\hline 9 & IAS 19 & The cost of employee benefit. & $\begin{array}{l}\text { Recognize as current service cost in } \\
\text { income statement. }\end{array}$ & Others & N/A \\
\hline 10 & IAS 20 & Accounting treatment for government grants & $\begin{array}{l}\text { Government grants are recognized in a } \\
\text { systematic profit and loss basis as long as } \\
\text { the period of the entity recognizes as } \\
\text { expenses on related costs intended to be } \\
\text { compensated by grants }\end{array}$ & Others & $\mathrm{N} / \mathrm{A}$ \\
\hline 11 & IAS 21 & $\begin{array}{l}\text { Treatment of foreign exchange differences } \\
\text { from the translation of foreign currency } \\
\text { statements }\end{array}$ & $\begin{array}{l}\text { Other comprehensive income }(\mathrm{OCI}) \text { from } \\
\text { the translation of reports in foreign } \\
\text { currency to the reporting currency is } \\
\text { presented as unrealized gains or losses in } \\
\text { the statement of profit or loss and other } \\
\text { comprehensive income in the OCI section } \\
\text { below net income and appears in the } \\
\text { equity section }\end{array}$ & Others & N/A \\
\hline 12 & IAS 27 & $\begin{array}{l}\text { The method used for separated financial } \\
\text { statements }\end{array}$ & $\begin{array}{ll}\text { a. } & \text { acquisition cost } \\
\text { b. } & \text { in accordance with IAS } 39 \\
\text { c. } & \text { using the equity method }\end{array}$ & Others & $\mathrm{N} / \mathrm{A}$ \\
\hline 13 & IAS 30 & $\begin{array}{l}\text { Criteria used by the company in determining } \\
\text { finance leases }\end{array}$ & $\begin{array}{l}\text { Individually or jointly has the following } \\
\text { characteristics: } \\
\text { a. lease transfers ownership of } \\
\text { assets to the lessee at the end of the lease } \\
\text { term. } \\
\text { b. Lessees have the option to buy assets } \\
\text { at prices that are estimated to be quite low } \\
\text { compared to the fair value on the date } \\
\text { the option starts to be implemented so } \\
\text { that at the beginning of the lease it can be } \\
\text { ascertained that the option can be } \\
\text { implemented. } \\
\text { c. The lease term is for most of the } \\
\text { economic life of the asset even though } \\
\text { the ownership rights are not transferred. } \\
\text { d. At the beginning of the lease, the }\end{array}$ & Others & \\
\hline
\end{tabular}




\begin{tabular}{|c|c|c|c|c|c|}
\hline & & & $\begin{array}{l}\text { present value of the minimum lease } \\
\text { payments is substantially close to all the } \\
\text { fair value of the leased assets. } \\
\text { e. Rental assets are special, and only } \\
\text { lessees can use them without the need for } \\
\text { material modifications. }\end{array}$ & & \\
\hline 14 & IAS 38 & Measurement $\quad$ of intangible assets & $\begin{array}{l}\text { The entity chooses a cost model or } \\
\text { revaluation model as its accounting policy. }\end{array}$ & Others & $\mathrm{N} / \mathrm{A}$ \\
\hline 15 & IAS 38 & Measurement of Goodwill & $\begin{array}{l}\text { The company examines the decline in } \\
\text { Goodwill value on an annual basis. }\end{array}$ & Others & N/A \\
\hline 16 & IAS 39 & $\begin{array}{l}\text { Gains or losses on financial assets classified } \\
\text { as available for sale }\end{array}$ & $\begin{array}{l}\text { Recognized in other comprehensive } \\
\text { income until the asset is derecognized. At } \\
\text { that time the cumulative gain or loss } \\
\text { previously recognized in other } \\
\text { comprehensive income is reclassified from } \\
\text { equity to profit or loss as a reclassification } \\
\text { adjustment. }\end{array}$ & Others & N/A \\
\hline 17 & IAS 39 & Gains or losses on cash flow hedges & $\begin{array}{l}\text { Part of the gain or loss on the hedging } \\
\text { instrument designated as an effective } \\
\text { hedge is recognized in other } \\
\text { comprehensive income }\end{array}$ & Others & N/A \\
\hline 18 & IAS 40 & Measurement of investment property & $\begin{array}{l}\text { Investment property is measured by choice } \\
\text { of cost models or fair value models and is } \\
\text { considered an indication of impairment }\end{array}$ & Others & N/A \\
\hline 19 & IFRS 4 & $\begin{array}{l}\text { Related to the liability of the insurance } \\
\text { company }\end{array}$ & $\begin{array}{l}\text { The company tests the adequacy of } \\
\text { liabilities at the end of the reporting period } \\
\text { using the gross premium reserve (GPR) } \\
\text { method for which all estimated present } \\
\text { value of cash in and out (premiums, } \\
\text { claims, or benefits and costs) are taken } \\
\text { into account. }\end{array}$ & Others & \\
\hline 20 & IFRS 4 & Related to life insurance company liabilities & $\begin{array}{l}\text { The company tests the adequacy of } \\
\text { liabilities at the end of the reporting period } \\
\text { using the gross premium reserve (GPR) } \\
\text { method for which all estimated present } \\
\text { value of cash in and out (premiums, claims, } \\
\text { or benefits and costs) are taken into } \\
\text { account. }\end{array}$ & Others & $\mathrm{N} / \mathrm{A}$ \\
\hline 21 & IFRS 3 & $\begin{array}{l}\text { The difference between the amount of } \\
\text { consideration transferred and the carrying } \\
\text { amount of each business combination } \\
\text { transaction between entities under common } \\
\text { control }\end{array}$ & Presented in additional paid-in capital & Others & N/A \\
\hline 22 & IFRS 5 & $\begin{array}{l}\text { Measurement of non-current assets as owned } \\
\text { for sale }\end{array}$ & $\begin{array}{l}\text { At a lower value between the carrying } \\
\text { amount and fair value less costs to sell }\end{array}$ & Others & N/A \\
\hline 23 & IFRS 10 & $\begin{array}{l}\text { Ownership terms used in } \\
\text { consolidated financial statements }\end{array}$ & Non-controlling interests & Others & N/A \\
\hline 24 & IFRS 11 & $\begin{array}{ll}\text { Accounting } & \text { treatment in venturers } \\
\text { in joint ventures } & \end{array}$ & $\begin{array}{l}\text { The joint venture recognizes its interest in a } \\
\text { joint venture as an investment and records } \\
\text { the investment using the equity method } \\
\text { in accordance with IAS } 28\end{array}$ & Others & $\mathrm{N} / \mathrm{A}$ \\
\hline
\end{tabular}

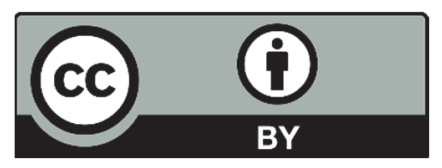

(C) 2021 by the authors; licensee Growing Science, Canada. This is an open access article distributed under the terms and conditions of the Creative Commons Attribution (CC-BY) license (http://creativecommons.org/licenses/by/4.0/). 